\title{
Land suitability model for rubber in Moneragala district: first approximation using GIS
}

\author{
Senani Karunaratne*, Jagath Gunathilake**, Wasana Wijesuriya***, \\ Keminda Herath* and Lalani Samarappuli*** \\ * Faculty of Agriculture \& Plantation Management, Wayamba University of Sri Lanka, \\ Makandura, Gonawila (NWP), Sri Lanka \\ ** Postgraduate Institute of Science, University of Peradeniya, Peradeniya, Sri Lanka \\ ***Rubber Research Institute of Sri Lanka, Dartonfield, Agalawatta, Sri Lanka
}

Received 05 December 2011; Accepted 23 January 2012

\begin{abstract}
Rubber is one of the major plantation crops grown in Sri Lanka, which generates foreign earnings to the country. To cope up with the increasing demand for rubber in both local and international markets it is vital to increase the extent under rubber cultivation. Expansion of rubber into intermediate and dry zone areas of Sri Lanka is focused in rubber development activities to achieve the national production targets. Hence, the objective of this study is to develop a land suitability map for rubber in Moneragala district and to identify potential land uses for further expansion of rubber in this district. The study was carried out in GIS environment using weighted overlaying technique. Results from the suitability analysis revealed that, the DS division, Madulla has the highest extent of 'most suitable' category (1289 ha) while Wellawaya and Siyambalanduwa have $480 \mathrm{ha}$ and $476 \mathrm{ha}$, respectively. The information derived through this study offer a ground for the policy makers for effective decision making on expanding rubber cultivation in the Moneragala district.
\end{abstract}

Key words: GIS, land suitability modeling, Moneragala district

\section{Introduction}

Rubber is one of the major plantation crops grown in Sri Lanka, which generate foreign exchange earnings to the country. Sri Lanka had around 229,000 ha under rubber in the 1960s but currently the land area under rubber is 126,000 ha (Anon, 2010). This decline of land extent under rubber was more prominent during 2001 and 2002 (Anon, 2005). The major reason for this decline is due to unstable prices for rubber products as well as the high cost of production compared to other rubber producing countries. As a result, the 
extent under rubber decreased and consequently the total rubber production also decreased. During this period, most of the rubber lands in the wet zone were diversified into other crops such as Oil Palm and also to plantation forestry. However, after year 2002 the improvement of rubber prices resulted in an increase in total extent under rubber due to replanting and new planting activities. However, the traditional rubber growing districts in the wet zone are subjected to various development activities restricting further expansion. The Government in response to this situation initiated a project to expand rubber into non traditional areas such as Moneragala, Badulla, Ampara and Hambantota districts. It was estimated that at the end of year 2007, total extent of rubber cultivation in the Moneragala District was 4,617 ha (Anon, 2007). Other than increasing the extent of rubber, this action will increase the forest cover of those areas, since rubber acts similar to a natural forest. It will also improve the social status of the poor people in these areas.

Rubber is a crop which has all its operations linked with the weather pattern, especially rainfall. Hence, proper planning is needed in the decision making process of where to expand rubber cultivation and also what agronomic recommendations are needed for a sustainable rubber cultivation (Wijesuriya et al., 2010). The GIS approach has been used in many occasions as a decision support tool in such development activities. This study employed the GIS approach to develop a land suitability map for rubber in Moneragala district and also to identify potential land uses for further expansion of rubber in the Moneragala district.

The practical implementation of combining the suitability criteria within the GIS environment is done with the help of cartographic modeling and the theoretical background relies on the methods of Multi-Criteria Evaluation (MCE). The main purpose in using MCE methods is to provide a basis for evaluating a number of alternative choice possibilities on the basis of multiple criteria (Nijkamp et al., 1990). Cartographic modeling is a technique where fundamental map processing operations are combined to perform more complex analysis (Berry, 1993). The simplest method of combining map layers in a situation when the objective is to choose those targets which fulfill certain criteria is to locate the targets fulfilling all the given criteria. This method is called the binary overlay method and it is based on utilizing the simple Boolean logic (Bonham-Carter, 1994). However, many problems are associated with the Boolean logic in combining the map layers (Carver, 1991). For instance, absolute classification imposes great demands in the determination of limit values. Furthermore, the binary overlay approach does not enable a more detailed analysis of alternatives, which could, for example, identify the most 
Senani Karunaratne et al.

suitable of the accepted alternatives or rejected alternatives.

Due to the problems associated with the use of Boolean logic, the use of methods based on MCE has become popular in the GIS environment (Carver, 1991; Pereira and Duckstein, 1993; Store and Kangas, 2001). By using the methods of MCE in combining criteria, one can avoid or mitigate many of the problems related to Boolean logic. Weighted linear summation is probably the best known MCE technique used in land-use problems. It is an additive technique where the total criterion score for each alternative is calculated by multiplying each standardized criterion score by its weight factor and then adding the results. Also some applications representing Analytic Hierarchy Process (AHP) have been introduced in the GIS environment (Siddiqui et al., 1996; Store and Kangas, 2001). In addition to additive techniques, multiplicative priority functions have also been used in combining criteria (Kurttila et al., 2002). The multiplicative model places weight on the large and small values of the variables. If one of the values of the criteria is zero, then the total criterion score is also zero. It favours the values of criterion variables near one another and so it is especially useful when even values are expected from different criteria. In this analysis Weighted Overlaying Technique was used to derive the suitability map.

\section{Methodology}

\section{Data}

The following digital data layers were used in this study.

- Land use maps $(1: 50,000)$ map sheets from Survey Department of Sri Lanka

- Updated land use maps $(1: 50,000)$ from the Regional Office of Land Use Division, Moneragala.

- Contour Maps $(1: 50,000)$ from the Survey Department of Sri Lanka

- Soil Map from the Natural Resource Management Centre, Department of Agriculture

- Rainfall and temperature data from Department of Meteorology and Natural Resource Management Centre, Department of Agriculture

\section{Software}

Preparation of maps and analysis of spatial data were performed using ARC GIS 9.2 (Arc/Info) version. Post processing of the collected GPS points was done through Ozi-Explorer software. The analysis was carried out in raster environment and all the outputs were generated at $500 \mathrm{~m}$ grid size.

\section{Preparation of rainfall and} temperature maps of the area

The annual rainfall data of the rainfall recording stations in the Moneragala District were collected from the Department of Meteorology and Department of Agriculture. The data were recorded from 1976 to 2006 on an annual basis. Total of thirty nine (39) rainfall stations were marked in GIS 
using their GPS locations and corresponding average annual rainfall was calculated for each and every weather station. The Inverse Distance Weighted (IDW) algorithm was used to interpolate point data.

Due to limited number of weather stations which record temperature, island wide temperature recording stations were selected. The GPS locations of those weather stations were used to create a point data layer in the GIS environment. In case of temperature, thematic maps were produced for maximum and minimum temperatures, respectively. The IDW algorithm was used to interpolate the point data.

\section{Development of the Digital Elevation Model (DEM)}

The contour data from 1:50,000 map sheets available from the Survey Department of Sri Lanka were used to develop the Triangulated Irregular Network (TIN). The prepared TIN was used to derive the DEM. The DEM was used to assess the different elevation classes and to evaluate the suitability with respect to the elevation.

\section{Development of the slope map}

The developed DEM was used to derive the slope map of the study area as a primary terrain attribute. Slope was calculated as a percentage.

\section{Development of the land suitability map}

Land suitability index was derived for the study area with the aid of equation
01 . The weighted overlaying technique was used for this purpose.

$$
R_{i}=\frac{\sum W_{j} \cdot X_{i j}}{100}
$$

Where:

$\mathrm{R}_{\mathrm{i}}$ is the capability value of a place $\mathrm{i}$ in the developed suitability map

$\mathrm{Wj}$ is the weight of the factor $\mathrm{j}$

$\mathrm{Xij}$ is the ordinal rank capability of factor $j$ in the place $i$

The main variables included in the model were climatic, soil and topographic factors. The weights were allocated to the main variables in the model according to their influence on rubber tree growth and performances. The scientists from Rubber Research Institute of Sri Lanka were involved in the process of allocating weights. Once the weights were allocated to the main variables, ranking was done for subvariables from 1 to 12 (1 was allocated for best suited condition while 12 was allocated for the worst condition). The summary of the weight allocation and analysis is depicted in Annexure 1. Once the land suitability map was derived it was overlaid with annual cumulative rainfall. Then spatial operation was carried out to extract areas of the developed suitability maps, where mean annual rainfall is greater than $1650 \mathrm{~mm}$. Then the extracted suitability maps were clipped with potential land use categories that can be used for expansion of rubber. Finally, statistics were generated for 
Senani Karunaratne et al.

corresponding suitability classes in GIS environment with respect to DS divisions in the Moneragala district.

\section{Validation of the derived suitability model using existing rubber grown area}

The land suitability model derived from the analysis was tested with the current rubber growing areas. In order to map current rubber growing areas, a field survey was conducted using Garmin etrex handheld Global Positioning System (GPS). Seventeen rubber growing villages scattered throughout the Moneragala District were randomly marked as points using GPS. The collected points were post-processed using Ozi-Explorer software and were incorporated to GIS. Later, those points were overlaid with derived land suitability model and assessment was done for current rubber growing areas.

\section{Results and Discussion \\ Allocation of weights and ranks for rubber land suitability map}

In the process of allocation of weights, higher portion has been allocated to annual cumulative rainfall (60\%). Rainfall is the most important factor which influences rubber tree growth and performance (Yogaratnam, 2007). Ranking was performed based on the rainfall classification for rubber (Annexure 1). According to Yogaratnam (2007) annual cumulative rainfall between $1750 \mathrm{~mm}$ to $2000 \mathrm{~mm}$ was identified as ideal annual cumulative rainfall for rubber. Rainfall more than $2000 \mathrm{~mm}$ per annum is given second best rank mainly due to the possibility of spreading fungal diseases with the increasing rainfall. Annual cumulative rainfall less than $1250 \mathrm{~mm}$ is given lowest rank, since at this condition growth performances of the rubber plants are severely affected (Yogaratnam, 2007).

Mean annual maximum and mean annual minimum temperatures were given $2 \%$ of weight, respectively. Low weights indicate that they have less ability to influence rubber tree growth and performances. Best rank was allocated for annual minimum temperature between $20{ }^{\circ} \mathrm{C}$ to $25{ }^{\circ} \mathrm{C}$ while, worst rank was allocated to temperature below $15{ }^{\circ} \mathrm{C}$ (Yogaratnam, 2001). For annual maximum temperature, best ranks were allocated for temperature ranges; $24{ }^{\circ} \mathrm{C}$ to $26{ }^{\circ} \mathrm{C}$ and $26{ }^{\circ} \mathrm{C}$ to $28{ }^{\circ} \mathrm{C}$.

Slope is also an important topographic factor which influences rubber tree performances as well as cultural practices. Hence, $15 \%$ was allocated for slope from the final weight. Best ranks were given for slope classes less than $20 \%$ and $20 \%$ to $45 \%$, respectively. The worst rank was given for slope classes above $45 \%$ as it was reported by Yogaratnam (2001), that rubber is not advisable to cultivate above $45 \%$ slopes.

Elevation was give a weight of $6 \%$. Rubber trees perform well in low altitude i.e less than $200 \mathrm{~m}$ amsl. As a 
result, best rank was given to elevation class less than $200 \mathrm{~m}$ amsl. When considering the soil, $15 \%$ of the weight was allocated from the final weight. According to Yogaratnam (2001), rubber grows well under major soil series such as Red Yellow Podzolic soils, Reddish Brown Latosolic soils and in Immature Brown Loams. As a result best ranks were allocated to those soil series and its associates. Most parts of the Moneragala district consist of Reddish Brown Earth and its associates as the major soil group. Hence, moderate ranks were allocated for those soil groups. The worst ranks were given to soil groups such as, Erosional Remnants and Steep Rockland and Lithosols as they do not have desirable characteristics required for successful growth of rubber plants.

\section{Rubber land suitability map for Moneragala district}

The proposed land suitability map for rubber cultivation in the Moneragala District is depicted in Figure 1. The area which is identified as most suitable can be effectively used to expand rubber or to continue planting without any difficulties. However, in the areas which were identified as suitable and moderately suitable should be given much emphasis on moisture conservation. Proper agronomic practices need to be adopted in order to strive well under mid-year dry period. In these areas, special consideration should be given to young rubber plantations. Expansion of rubber in areas, which were identified as unsuitable and most unsuitable is not advisable. Monitory returns from rubber, which is a perennial crop with an economic life span of 24 years will be deprived if rubber is planted in these areas.

The summary of the suitability classes under each category is given in Table 1. However, some of these lands, although found in the desirable category were under land uses which cannot be converted into rubber. The updated land use maps from the Regional Land Use Division, Moneragala were used to identify the potential land uses that can be effectively used to expand rubber. Under potential land uses, four categories were identified i.e. Barren land, Grass land, Scrubs and underutilized land uses.

Table 1. Land suitability classes in the Moneragala district

\begin{tabular}{lrr}
\hline Category & $\begin{array}{r}\text { Area } \\
\text { (ha) }\end{array}$ & $\begin{array}{r}\text { Percentage } \\
\text { (\%) }\end{array}$ \\
\hline 1 & 31,625 & 5.55 \\
2 & 194,075 & 34.08 \\
3 & 46,800 & 8.22 \\
4 & 225,875 & 39.67 \\
5 & 59,850 & 10.51 \\
6 & 1,050 & 0.18 \\
7 & 8,350 & 1.47 \\
8 & 1,825 & 0.32 \\
\hline Total & 569,450 & 100.00 \\
\hline
\end{tabular}

Note - Most suitable to most unsuitable categories vary from 1 to 8 , respectively 


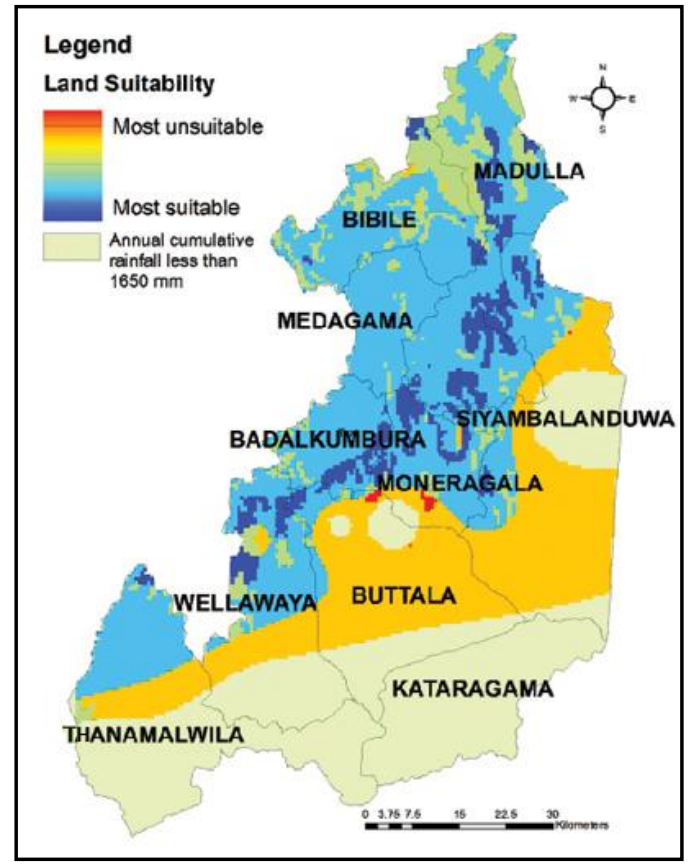

Note - Grid values vary from 1 to 8 for most suitable to most unsuitable, respectively.

Fig. 1. Land suitability map for rubber within the Moneragala district

Conversion of grasslands and scrubs to rubber is more beneficial since, rubber will act as a natural forest. Furthermore, annual fires which burn most of grasslands and scrubs due to anthropogenic activities will be discontinued. The resultant map obtained after clip operation of the potential land uses on the suitability map (Fig. 2) can be used as a guide to expand rubber in the Moneragala district.

Available extent for potential expansion of rubber on a DS division basis under each suitability category is given in Table 2. The extents under suitability classes i.e most suitable, suitable and moderately suitable, unsuitable and most unsuitable were analyzed with respect to different DS divisions. The results revealed that the Madulla, Wellawaya, Siyambalanduwa and Bibile respectively, have the highest extents of land under category, most suitable for rubber. These areas can be effectively used to expand rubber with minimum effort and with least resource wastage. 
Land suitability model for Moneragala district

Table 2. Distribution of extents with respect to DS divisions in the Moneragala district

\begin{tabular}{lrrrrr}
\hline & \multicolumn{5}{c}{ Extent under each suitability class (ha) } \\
\cline { 2 - 6 } DS Division & $\begin{array}{r}\text { Most } \\
\text { suitable }\end{array}$ & Suitable & Moderate & Unsuitable & $\begin{array}{r}\text { Most } \\
\text { unsuitable }\end{array}$ \\
\hline Bibile & 294 & 5522 & 2328 & 0 & 0 \\
Badalkumbura & 0 & 353 & 377 & 0 & 0 \\
Buttala & 77 & 309 & 42 & 3640 & 42 \\
Madulla & 1289 & 6475 & 1475 & 0 & 0 \\
Medagama & 0 & 4028 & 121 & 0 & 0 \\
Moneragala & 257 & 287 & 67 & 1252 & 17 \\
Siyambalanduwa & 476 & 3345 & 350 & 6949 & 0 \\
Thanamanwila & 0 & 7016 & 342 & 5783 & 0 \\
Wellawaya & 480 & 2593 & 660 & 952 & 0 \\
Kataragama & 0 & 0 & 0 & 0 & 0 \\
\hline
\end{tabular}

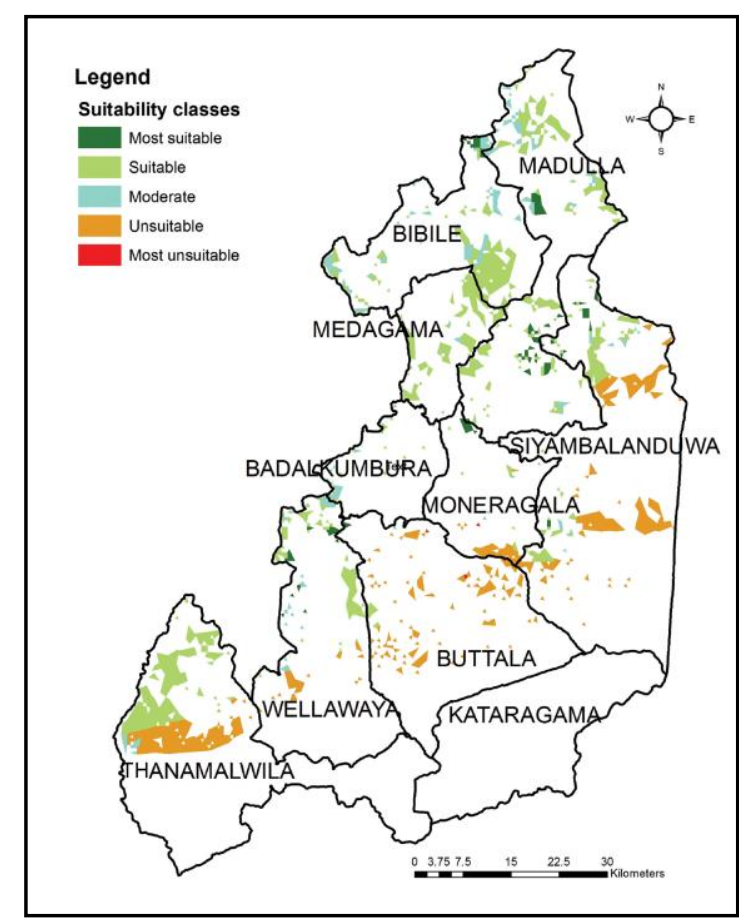

Fig.2. The potential areas for expansion of rubber 
Senani Karunaratne et al.

Validation of the derived land suitability model using existing rubber grown area

It was revealed that most of the rubber growing areas are located in most suitable and suitable areas of the derived land suitability map (Fig. 2). Areas such as Badalkumbura, Atale, Degalaramba, Moragahamada etc. are found in the most suitable region of the derived suitability model while Bibile, Kohombe, Siyambalagune etc. are located in the suitable region of the derived model. Rubber plantations in the Udugama area are found in the moderately suitable area in the derived land suitability map.

\section{Conclusions}

Areas categorized under most suitable can be effectively used to expand rubber with minimum effort. The total extent under most suitable, suitable and moderately suitable are 2873 ha, 29,928 ha and 5762 ha, respectively. These lands can be effectively used for rubber cultivation. Most of the areas where rubber is currently grown are found within the most suitable and suitable areas of the derived land suitability model. Therefore, it can be concluded that the existing rubber plantations in the Moneragala district can achieve higher yields through adopting proper agro-management practices.

Allocating weights to main variables and scores for sub-variables using a scale is subjective from person to person depending on the person's knowledge of expertise. Further, this may change depending on his/her research interest. Hence, use of fuzzy overlay techniques will enhance the outputs more realistically compared to discrete analysis.

The outcomes of this study can be used as a ground base of information to plan detailed analysis of the suitable areas to expand rubber within the district. Further refinement of this exercise is possible by incorporating more land suitability indicators.

\section{Acknowledgement}

The financial support given by the National Science Foundation of Sri Lanka under the grant RG/ 2006/EPSD/01 is highly appreciated. Authors extend their gratitude to $\mathrm{Dr}$ Nishantha Attanayake of Uva Wellasa University for his valuable comments on the analysis. The assistance given by Mr W J M Dayaratne, District Land Use Planning Officer, Moneragala is also greatly acknowledged.

\section{References}

Anon (2005). Plantation Sector Statistical Pocket Book, Ministry of Plantation Industries, Colombo 2.

Anon (2007). Statistics available from http:// www.rubberdev.gov.lk/ (Accessed on 5th February, 2009)

Anon (2010). Central Bank Annual Report Colombo, Sri Lanka.

Berry, J (1993). Cartographic modeling: the analytical capabilities of GIS. In: Goodchild, M., Parks, B., Steyaert, L. (Eds.) Environmental Modeling with GIS. Oxford University Press, New York, pp. 58-74. 
Bonham-Carter, G (1994). Geographic Information Systems for Geoscientists: Modeling with GIS. Computer Methods in the Geosciences 13, Pergamon, Ottawa, p.398.

Carver, S (1991). Integrating multi-criteria evaluation with geographical information systems. International Journal of Geographic Information Systems 5, 321-339.

Kurttila, M, Pukkala, T and Loikkanen, J (2002). The performance of alternative spatial objective types in forest planning calculations: a case for flying squirrel and moose. Forest Ecology Management 166, 245-260.

Nijkamp, P, Rietveld, P and Voogd, H (1990). Multicriteria Evaluation in Physical Planning. Contributions to Economic Analysis. North-Holland, p.219.

Pereira, J and Duckstein, L (1993). A multiple criteria decision making approach to GIS based land suitability evaluation. International Journal of Geographic Information Systems 7, 407424.

Siddiqui, M Z, Everett, J W and Vieux, B E (1996). Landfill site selection using geographic information systems: a demonstration. Journal of Environmental Engineering 122, 515523.
Store, R and Kangas, J (2001). Integrating spatial multi-criteria evaluation and expert knowledge for GIS-based habitat suitability modelling. Landscape Urban Planning 55, 79-93.

Wijesuriya, Wasana, Herath, Keminda and Karunaratne, Senani (2010). Use of rainfall patterns for efficient operation of agronomic practices in rubber plantations: The case of Moneragala district. Bulletin of the Rubber Research Institute of Sri Lanka 51, 70-80.

Yogaratnam, N (2001). Land suitability evaluation, selection and soil conservation. In: Handbook of Rubber, Vol.1, Agronomy pp. 1-11 (Eds. L. M. K Tillekeratne and A. Nugawela), Rubber Research Institute of Sri Lanka, Agalawatta, Sri Lanka.

Yogaratnam, N. (2007). Developments in rubber growing are impressive but still deficient. Journal of the National Institute of Plantation Management 23 (1), 14- 24.

Address for correspondence: Dr (Mrs) Wasana Wijesuriya, Biometrician, Rubber Research Institute of Sri Lanka, Dartonfield, Agalawatta, Sri Lanka.

e-mail:wasanaw@sltnet.lk. 
Annexure 01. Weights allocated for main variables and their sub categories

\begin{tabular}{|c|c|c|c|}
\hline Main variable & $\begin{array}{l}\% \\
\text { contribution }\end{array}$ & Sub categories & Rank \\
\hline \multirow{5}{*}{$\begin{array}{l}\text { Rainfall - } \\
\text { annual (mm) }\end{array}$} & 60 & Less than 1250 & 10 \\
\hline & & $1250-1499$ & 6 \\
\hline & & $1500-1749$ & 4 \\
\hline & & $1750-2000$ & 1 \\
\hline & & More than 2000 & 2 \\
\hline \multirow{5}{*}{$\begin{array}{l}\text { Min Temp - } \\
\text { annual }\left({ }^{\circ} \mathrm{C}\right)\end{array}$} & 2 & Less than 15 & 12 \\
\hline & & $15-16$ & 10 \\
\hline & & $16-18$ & 8 \\
\hline & & $18-20$ & 2 \\
\hline & & $20-25$ & 1 \\
\hline \multirow{7}{*}{$\begin{array}{l}\text { Max Temp - } \\
\text { annual }\left({ }^{\circ} \mathrm{C}\right)\end{array}$} & 2 & $16-17$ & 12 \\
\hline & & $17-19$ & 11 \\
\hline & & $19-22$ & 10 \\
\hline & & $22-24$ & 9 \\
\hline & & $24-26$ & 1 \\
\hline & & $26-28$ & 1 \\
\hline & & $28-33$ & 3 \\
\hline \multirow[t]{3}{*}{ Slope (\%) } & 15 & Less than 20 & 1 \\
\hline & & $20-45$ & 3 \\
\hline & & More than 45 & 10 \\
\hline \multirow[t]{4}{*}{ Elevation (m) } & 06 & Less than 200 & 1 \\
\hline & & $200-400$ & 1 \\
\hline & & $400-600$ & 4 \\
\hline & & More than 600 & 7 \\
\hline \multirow[t]{8}{*}{ Soil } & 15 & $\begin{array}{l}\text { Reddish Brown Earths \& Low Humic gley soils; } \\
\text { undulating terrain }\end{array}$ & 6 \\
\hline & & $\begin{array}{l}\text { Alluvial soils of variable drainage and texture; flat } \\
\text { terrain }\end{array}$ & 8 \\
\hline & & $\begin{array}{l}\text { Reddish Brown Earths \& Immature Brown Looms; } \\
\text { rolling, hilly and steep terrain }\end{array}$ & 3 \\
\hline & & Reddish Brown Earths, Noncalcic Brown soils \& & 6 \\
\hline & & Low Humic gley soils; undulating terrain & \\
\hline & & Erosional remnants (Inselbergs) & 12 \\
\hline & & Rock knob plain & 6 \\
\hline & & $\begin{array}{l}\text { Red-Yellow Podzolic soils \& Mountain Regosols; } \\
\text { mountainous terrain }\end{array}$ & 2 \\
\hline
\end{tabular}


Land suitability model for Moneragala district

\begin{tabular}{llr}
\hline Main variable $\begin{array}{l}\% \\
\text { contribution }\end{array}$ & Sub categories & Rank \\
& & 2 \\
& Red-Yellow Latosols; flat to slightly undulating \\
& terrain \\
& Reddish Brown Earths \& Low Humic gley soils; & \\
& undulating terrain & 6 \\
& Reddish Brown earth \& solodized solonetz, & \\
& undulating terrain & 6 \\
& Reddish Brown Earths with high amount of gravel in & 7 \\
& subsoil \& Low Humic Gley soils; undulating terrain & \\
& Solodized solonetz and solonchaks, flat terrain & 9 \\
& Steep rockland \& Lithosols & 12 \\
& Non calcic brown & 5 \\
\hline
\end{tabular}

Note - Rank 1 was assigned to the best situation while 12 was assigned to the worst situation. 